\title{
The Brandeis Science Posse: Using the Group Model to Retain Students in the Sciences
}

\author{
By Irv Epstein \\ Kim Godsoe ${ }^{\dagger}$ \\ Melissa Kosinski-Collins ${ }^{t}$
}

For the past five years, the Brandeis Science Posse program has recruited and retained students from underrepresented groups in STEM disciplines. In collaboration with the Posse Foundation, we have facilitated the formation of a close-knit, mutually supportive learning community, or a "science posse" for sixty students from New York City public high schools. We have investigated how resilience has impacted retention of Science Posse Scholars in STEM fields. We have found that Science Posse Scholars have multiple criteria by which they evaluate personal success and that an upward trajectory over their STEM career leads to their overall resilience. Helping students articulate and define personal perceptions of success throughout their academic career may help retain them in STEM fields.

\section{Introduction}

A major area of debate in higher education in the United States is how to best retain underrepresented racial minority students (URM) in Science, Technology, Engineering and Mathematics (STEM). The most highly selective colleges and universities in the United States graduate Blacks and Latinos at a higher rate than less selective colleges and universities, yet these same institutions are less likely to retain underrepresented students in the sciences (Alon and Tienda, 2005; Bowen and Bok, 1998; Huang et al., 2000; NSF, 2004.)

Resilience is defined as the fixed trait of an individual (Masten, 2001) or as the relationship between an individual and people or organizations (Luthar et al., 2000). Cabrera and Padilla (2004, p. 152) defined students who were educationally resilient as individuals who "despite economic, cultural, and social barriers still succeed [academically] at high levels". Stanton-Salazar and Spina (2000) identified resilience as a navigational skill that allows students to not only survive stressful events but use those events to positively shape future events. Lee et al. (2013) found that the most important factors in resilience

\footnotetext{
*Professor, Brandeis University, USA.

${ }^{\dagger}$ Associate Provost, Brandeis University, USA.

${ }^{\star}$ Associate Professor, Brandeis University, USA.
} 
were life satisfaction, optimism, positive affect, self-efficacy, self-esteem and social support.

While resilience has been used to examine issues of retention, there has been relatively little use of the theory in research about retention in science. Previous research has demonstrated that the greatest predictor of retention in STEM at highly selective colleges and universities was first-year and secondyear science grades, (Strenta et al., 1994). Students who do not experience high grades, particularly after devoting large amounts of study time, will not benefit from these positive feelings, and they will need to navigate feelings of doubt about their academic abilities in science. The ability to tolerate these feelings and continue in STEM is a form of resilience.

We examined how resilience impacted retention of students in science in the Brandeis Science Posse program. All of the students selected for the program were interested in studying science at the college level. Posse Scholars were overwhelmingly URM students, first-generation college students and/or low-income students. As of September 2012, 70\% of the Science Posse Scholars had declared a major in STEM fields.

We investigated how Science Posse Scholars understood their success in science. Proxies for resilience in our analysis included how students navigated feelings of competition, study behaviors and thoughts of leaving science, perceptions of the impact of gender and race on the study of science, and the degree to which students perceived themselves as successful in the sciences.

\section{Backround on the Science Posse}

\section{History of the Science Posse Scholars Program}

The Posse Foundation is a non-profit organization based in New York City dedicated to increasing the leadership pool and diversity of U.S. college campuses. Posse scholars receive four-year, full tuition scholarships from the universities they attend. All ten Scholars in a Posse come from the same city and attend the same institution. Ninety percent of Posse Scholars have graduated from college (http://www.possefoundation.org/about-posse). The Brandeis Posse students have excelled and have had an overall 90\% graduation rate. In this traditional Posse model, there is no expectation on student major selection. In an attempt to increase student retention in the sciences, the Science Posse was founded in 2008 at Brandeis.

\section{The Science Posse Selection Process}

The Science Posse Scholars selection process (Table 1) emphasized leadership, communication, and problem solving skills rather than the traditional admissions metrics of standardized test scores such as the SAT and grades. Because the program was based in a large urban area, the majority of the students selected as Scholars were URM or first-generation college students or students from families with limited financial opportunities.

Students were nominated for the Science Posse Scholarship by schools and 
non-profit organizations in New York City because of their academic success, leadership skills and demonstrated interest in the sciences. Students were then selected for the scholarship through a three-step Dynamic Assessment process including group interviews, individual interviews, problem solving tasks and group presentations (Bial, 2007).

Table 1. Science Posse Scholars Selection Process for Brandeis University

\begin{tabular}{|c|c|c|}
\hline Event & Time of Year & $\begin{array}{c}\text { Number of } \\
\text { students }\end{array}$ \\
\hline $\begin{array}{c}\text { School and community organizations nominate } \\
\text { outstanding student leaders }\end{array}$ & $\begin{array}{c}\text { August/ } \\
\text { September }\end{array}$ & 3,800 \\
\hline $\begin{array}{c}\text { Dynamic Assessment Process (DAP): } \\
\text { students are identified for leadership and } \\
\text { communication skills }\end{array}$ & $\begin{array}{c}\text { September/ } \\
\text { October }\end{array}$ & 3,500 \\
\hline $\begin{array}{c}\text { Individual interviews , } \\
\text { students express interest in STEM }\end{array}$ & $\begin{array}{c}\text { October/ } \\
\text { November }\end{array}$ & 1,750 \\
\hline $\begin{array}{c}\text { Finalist pool selected for Science Posse at } \\
\text { Brandeis }\end{array}$ & December & 20 \\
\hline Brandeis Science Posse Scholars selected & December & 10 \\
\hline
\end{tabular}

The demographic information for the Science Posse and non-science Posse Brandeis student populations is provided in Table 2.

Table 2. Characteristics of Brandeis Science Posse Students as Compared to All Other Brandeis Students

\begin{tabular}{|c|c|c|}
\hline Demographic Characteristic & Science Posse & Brandeis Population \\
\hline Gender & & \\
\hline Male & $52.5 \%$ & $43.4 \%$ \\
\hline Female & $47.5 \%$ & $56.6 \%$ \\
\hline Race & & \\
\hline African-American & $35 \%$ & $4.1 \%$ \\
\hline Asian-American & $22.5 \%$ & $15.1 \%$ \\
\hline Latino/Hispanic & $37.5 \%$ & $5.6 \%$ \\
\hline White & $2.5 \%$ & $55.2 \%$ \\
\hline Native American & $0 \%$ & $0.3 \%$ \\
\hline Unknown & $2.5 \%$ & $16.9 \%$ \\
\hline Other characteristics & & \\
\hline Average SAT score & 1156 & 1331 \\
\hline Need-based federal grant eligible & $70 \%$ & $19.3 \%$ \\
\hline First generation status & $77.5 \%$ & $14.4 \%$ \\
\hline
\end{tabular}

Science Posse Scholars Program Activities 
All Scholars participated in an eight-month pre-collegiate training (PCT), three science workshops, and a twelve-day Summer Science Immersion Program (Table 3).

The pre-collegiate training occurred weekly from January through August in the students' senior year of high school. The training emphasized leadership development and problem solving skills with weekly workshops that included activities such as a discussion of race, religious beliefs, or a Myers-Briggs personality test. During pre-collegiate training, there were only three sessions that focused on STEM.

Table 3. Activities Associated with the Science Posse Program

\begin{tabular}{|c|c|c|c|}
\hline Event & Time of Year & Time & $\begin{array}{c}\text { Mandatory or } \\
\text { Optional }\end{array}$ \\
\hline $\begin{array}{c}\text { Weekly PCT emphasizing } \\
\text { leadership and } \\
\text { communication skills }\end{array}$ & $\begin{array}{c}\text { January through August } \\
\text { of senior year high school }\end{array}$ & $\begin{array}{c}2 \text { hours/ } \\
\text { week }\end{array}$ & Mandatory \\
\hline $\begin{array}{c}\text { Three STEM workshops } \\
\text { within PCT are devoted to } \\
\text { science: } 1 \text { chemistry, } \\
\text { biology, } 1 \text { math }\end{array}$ & February, March, April & $\begin{array}{c}2 \text { hours/ } \\
\text { workshop }\end{array}$ & Mandatory \\
\hline $\begin{array}{c}\text { Summer Science Immersion } \\
\text { Program }\end{array}$ & July & 10 days & Mandatory \\
\hline $\begin{array}{c}\text { Weekly group meetings } \\
\text { emphasizing leadership } \\
\text { skills \& the transition to } \\
\text { college }\end{array}$ & $\begin{array}{c}\text { September through May } \\
\text { for the first two years of } \\
\text { college }\end{array}$ & $\begin{array}{c}2 \\
\text { hours/week }\end{array}$ & Mandatory \\
\hline $\begin{array}{c}\text { Individual meetings with } \\
\text { Science Posse Mentor }\end{array}$ & $\begin{array}{c}\text { September through May, } \\
\text { first two years of college }\end{array}$ & 1 hour every \\
other week & Mandatory \\
\hline Research Lab Experience & September through May & Varies & Optional \\
\hline
\end{tabular}

The twelve-day Summer Science Immersion provided exposure to college level work in the sciences but did not provide science remediation. Scholars had their first experience with the intensity of college level science, the grading curve that is used, feelings of competition, scientific communication and issues with time-management. The Summer Science Immersion could be viewed as socializing students into the sciences.

Once the Posse Scholars were enrolled as full-time students at Brandeis, they continued to meet as a cohort under the guidance of a mentor for their first two years. The mentor met weekly with the cohort as a group and individually with each scholar every other week to discuss personal development. Relatively little time was spent on science remediation.

In addition to meetings with the mentor, Science Posse Scholars were given the opportunity to work in a faculty member's research lab. Any Science Posse student interested was offered a paid position in a research lab on 
campus. Approximately, five to seven of each cohort participated in laboratory research their first year.

\section{Research Design}

Brandeis is a selective private research university that enrolls approximately 3,500 undergraduates and 1,400 graduate students. The qualitative analysis was conducted with data from 89 student interviews, including 38 Science Posse Scholars, 24 students from backgrounds similar to the Scholars (Underrepresented Students), and 25 students from well-resourced families (Table 4).

Comparison groups that closely resembled the diversity of the Science Posse Scholars were created from the student participants of the study. Of the forty Posse Scholars who were on campus at the time of the interviews, 30 were URM and 10 were White and Asian-American. In addition, 36 of the 40 Posse Scholars were first-generation and/or low-income. The comparison group for students from backgrounds similar to Science Posse Scholars was students who were first-generation and low-income. Like the Scholars, they were typically from less-resourced high schools, and they would have navigated college without the same level of preparation and support as more well-resourced students.

The minimum standard for the well-resourced group was that students have at least one parent with a bachelor's degree as well as an adjusted gross family income of at least $\$ 80,000$. These well-resourced students would have benefited from parents who were familiar with educational institutions and would have likely experienced economic stability and opportunity during their $\mathrm{K}-12$ years.

Students were also screened for their current major or intended major at entry. Science Posse Scholars who declared majors in the sciences have almost exclusively studied Biology, Chemistry, Physics and Neuroscience. In order to create the strongest comparison groups with Posse Scholars, interviews were conducted with students who entered Brandeis with similar majors (Table 4). 
Table 4. Comparison Groups for Qualitative Analysis

\begin{tabular}{|c|c|}
\hline $\begin{array}{l}\text { Comparison Group 1: } \\
\text { 38 Brandeis Science Posse } \\
\text { Scholars }\end{array}$ & $\begin{array}{l}\text { - Science Posse Scholars } \\
\text { - Most were first-generation college students and/or } \\
\text { low-income and/or underrepresented minorities } \\
\text { - First-years, sophomores, juniors, and seniors } \\
\text { - Entered college with the intention to major in } \\
\text { biology, biochemistry, chemistry, neuroscience or } \\
\text { HSSP; attempted at least one semester of sciences } \\
\text { intended for these majors } \\
\text { - } 9 \text { White or Asian-American students, } 29 \\
\text { underrepresented racial minority students }\end{array}$ \\
\hline $\begin{array}{l}\text { Comparison Group 2: } \\
\text { 24 Brandeis Students from } \\
\text { Backgrounds Similar to } \\
\text { Science Posse Scholars } \\
\text { (Underrepresented Students) }\end{array}$ & $\begin{array}{l}\text { - Non-Posse Scholars } \\
\text { - Students who were either first-generation college } \\
\text { students and/or Pell grant recipient } \\
\text { - First-years, sophomores, juniors, and seniors } \\
\text { - Entered college with the intention to major in } \\
\text { biology, biochemistry, chemistry, neuroscience or } \\
\text { HSSP; attempted at least one semester of sciences } \\
\text { intended for these majors } \\
\text { - } 10 \text { White or Asian-American students, } 14 \\
\text { underrepresented racial minority students }\end{array}$ \\
\hline $\begin{array}{l}\text { Comparison Group 3: } \\
25 \text { Brandeis Students from } \\
\text { Well-Resourced Families }\end{array}$ & $\begin{array}{l}\text { - Non-Posse Scholars } \\
\text { - From families with adjusted gross incomes of } \\
\$ 80,000 \text { or more or did not request financial aid to } \\
\text { attend Brandeis } \\
\text { - Had at least one parent with a bachelor's degree } \\
\text { - First-years, sophomores, juniors, and seniors } \\
\text { - Entered college with the intention to major in } \\
\text { biology, biochemistry, chemistry, neuroscience or } \\
\text { HSSP; attempted at least one semester of sciences } \\
\text { intended for these majors } \\
\text { - } 21 \text { White or Asian-American students, } 4 \\
\text { underrepresented racial minority students }\end{array}$ \\
\hline
\end{tabular}

\section{Results}

One indicator of resilience is student self-perception of success in science. Students who feel successful in the science classroom are more likely to be retained in STEM. In order to determine how students define success, we asked students to determine whether or not they had been successful in the sciences.

Most well-resourced students described themselves as successful in science. Their feelings of success were often linked to their academic performance. The theme of seeing positive results in the study of science was expressed by Faith, a well-resourced underclass student who planned to major in science. She said "I would say...I enjoy it, which, again, I think is a success in itself if you like what you are doing. But I think when I study something, and I take a test, it does work out. So that's a good feeling too." For Malcom, a 
well-resourced upper class student majoring in science, his success was very much a reflection of his grades, and he had determined that a B- (the typical average for a science course) was not being successful, but a B+ or A- was being successful. As long as he was in his self-defined range of success, he felt good about his abilities in science. He recalled:

I haven't calculated my science GPA, because I haven't needed to. But I have a good GPA. I'm planning on hopefully graduating with whatever that first honors is. And yeah, I do fine, as I said. I think one time I got a B-in a science class. One time....No, it was a B. And that I was like, "Okay. That stinks, but I'll do better." And then, usually I get $B+s, A-s . . . I ' m$ very happy with that.

While Faith and Malcolm focused on grades as a measure of success, other well-resourced students defined success based on research opportunities, publications, or developing a comprehensive knowledge of science that went beyond classroom instruction. Django, an upper class student majoring in science, had worked in a research lab since his first year of college. When asked about success, he said, "I am not proud of my grades anymore because I've been getting good grades for so long. The next level of success is research, which I haven't been successful in." For Django, having a publication in a peer-reviewed journal was his measure of success. Monica, a well-resourced upper class student majoring in science, said that her idea of success had broadened from simply doing well in her classes to demonstrating expertise in the sciences. She said:

Here at Brandeis...I guess somewhat successful in the sense that I've got research done, and did okay in my classes...In terms of the real world...I did the Harvard Medical School Summer Immunology Program. I presented at the New England Science Symposium and the Annual Biomedical Research Conference for Minority Students in California. But, it's getting to that level where you can actually dissect science and understand the problem.

Both Django and Monica had experienced strong grades in their science courses, so classroom achievement was no longer the measure they used to evaluate their success in the sciences.

Other well-resourced students did not feel successful in the sciences, which was largely a reflection of their grades in science classes. Their selfevaluations often compared themselves to their peers who were academically achieving. Valerie, an underclass student interested in health, described herself as "aggressively average" in the sciences and explained that she had friends who were "slamming the 4.0's." Another well-resourced upper class student majoring in science, Abby said that she wasn't successful in the sciences but she had "given up crying about my GPA." Ashley, a well-resourced underclass 
student interested in science, recounted the difference she felt in high school and college level science. She earned a $\mathrm{C}+$ in an entry level STEM course. She recounted earning A's in high school, and said that her experiences in college level science were "harsh," but success would be "improvement." For these students, they were all determined to stay in the sciences even if they were not earning higher grades, yet each showed the discouragement they felt because they weren't achieving at the level they hoped.

Underrepresented students also described themselves as successful. Unlike well-resourced students, their definition of success was not a reflection of high grades, but rather the progress they had made in learning to study science. Brandon, an underrepresented underclass student interested in science, explained this uphill trajectory:

I'm getting there. I always think that I can do better... I can always get that extra point, I can always get within the A range....So, I'm definitely getting to where I need to be, and there's always just a little bit more.

Chipmunk, an underrepresented upper class student majoring in science, also focused on her journey of learning how to study science. She explained how emotionally difficult it was for her to stay with the sciences ("I really cried a lot"), yet she persevered.

For Brandon and Chipmunk, success was defined as staying with the sciences, in spite of all of the difficulties that they faced. This determination to continue in spite of feelings of disappointment was a source of pride.

Other underrepresented students described their success within the context of their academic or family background in comparison to their peers. Again, the theme of continuing in the sciences despite of feelings of struggle was prevalent. Mark, an underrepresented underclass student interested in science, described how he thought of his academic success both in the context of grades and in the context of his family background. He explained:

\begin{abstract}
I feel like I am [successful] because I always tell myself it's always it's about this journey. And if I look at it in terms of grades, I would just - I would just transfer or something... So, I measure success in terms of where I started from... all I have learned, and all I have gained, all I've been through... If I look at just everything I've learned, I feel like it's been a very successful journey, and I'm glad I'm at Brandeis... I feel like, yes, I face obstacles in my life, but those obstacles helped shape who I am. And I feel like the sciences here also shaped who I am. So, I look at it with absolute success, because I'm still here; I'm still doing it.- I still want to learn science.
\end{abstract}

While underrepresented students acknowledged disappointment in having not done better, they valued how much they have had to overcome in order to be successful in the sciences. 
Science Posse Scholars also had mixed responses to whether or not they considered themselves as successful in science. A few Scholars said they felt successful, which was a reflection of their academic achievement. Zara, an underclass Science Posse Scholar planning on declaring a major in science, had similar feelings of accomplishment. She said, "Not to toot my own horn, but yeah...I feel like I can teach people about the sciences and be happy when I'm teaching them." For these Scholars, the definition of success was similar to well-resourced students' definition of academic achievement.

However, the majority of Science Posse Scholars did not feel successful in the sciences or felt they were still in the process of becoming successful. This theme of developing skills in learning was prevalent in many of the interviews. Students recognized their current level of accomplishment as defined by their grades, as well as valued the improvements they had made in their approach to studying. Tasha, an upper class Science Posse Scholar interested in health, explained, "I'd say me and science have a very awkward relationship." She explained that for her, success was not only about her academic performance, but also about having high standards and continuing to reach for those standards.

This theme of where one is and where one wants to be was also expressed by Kay, an underclass Science Posse Scholar interested in science. She described herself as both unsuccessful and successful in the sciences:

\begin{abstract}
If I go off my grades solely I'd say no, but if I think about what I've learned and what I've taken away from science and like what it has taught me about myself and about myself as a student, myself as a person, then I'd definitely say yeah that I'm successful in science....But as far as success like gradewise, not so much.
\end{abstract}

The ability to value progress in learning was expressed by Science Posse Scholars, and this progress helped to keep them motivated to stay in the sciences. This theme of an upward trajectory was expressed by Phoebe, an upper class Science Posse Scholar science major. She said, "I guess that I am becoming successful in the sciences." She thought of her success as how she "learned to study a little bit more, a little bit better for the sciences." This idea of science as a journey was similar to how underrepresented students described their success; they valued the progression they had made over time.

As with well-resourced students, Science Posse Scholars also described success as being more than doing well in their academic work. John, an upper class science major, thought of success as making meaningful contributions in research.

Successful, yes and no. Grade-wise, GPA-wise, no... But the development, the process, the learning process, yes. Now I understand what it takes to survive the sciences, and to be successful in the sciences. It's all about the results....The bench work is just 
Vol. 2, No. $1 \quad$ Epstein et al.: The Brandeis Science Posse: Using the Group Model...

persistent, and just patient. Patient and persistent, it's - GPA...will not make you the best researcher. It can get you very far in terms of get into labs and all that stuff. But publishing papers, publishing multiple papers depends on your patience and your persistent,... and your ability to think and to just think out of the box.

While well-resourced students thought of research as an extension of their success in the classroom, John thought of research as something that gave him a feeling of accomplishment in spite of his science grades. Joachim, an underclass Science Posse Scholar interested in science who had excelled by the traditional metrics of grades said that he did not feel successful. Like his wellresourced peers, he had a broader definition of success beyond grades. However, unlike his well-resourced peers, he did not derive feelings of academic success from his grades. He explained "Science is this amazing thing, and I feel like the more you know, the more you know that you don't know." For him being successful was going to graduate school, and he explained, "So I don't think I'm successful yet, but I want to get there one day."

Other Science Posse Scholars linked feeling successful to achieving professional positions later in life. For these students, college was one step in a multi-step journey leading to graduate school. Carolyn, an underclass Science Posse Scholar interested in science, defined her success with a career outcome. She said, "The only way I would say I'm successful is when I [am accepted to graduate school]. So like in the future, at least two years, if I win any little award, I'm, like, 'Oh, okay, it's just an award.' I have not reached what I want to reach." Aaron, an upper class Science Posse Scholar science major, was thinking of attending graduate school. He said that while he felt successful, "I still have a long way to go." While each of these students would have been considered as having strong levels of academic achievement, they did not internalize their grades as an indicator of success. Instead, they measured success by their future career success. The results for all three groups are summarized in Table 5. 
Table 5. Comparison of Students' Perceptions of Success in the Sciences

\begin{tabular}{|c|c|c|}
\hline Well-Resourced Students & $\begin{array}{l}\text { Underrepresented } \\
\text { Students }\end{array}$ & Science Posse Scholars \\
\hline \begin{tabular}{|l} 
Most feel successful as \\
a reflection of their \\
academic performance \\
Some define success as \\
research or further \\
scientific knowledge \\
Resilience is \\
demonstrated as \\
students find the study \\
of science challenging \\
but they feel successful \\
because of traditional \\
measures such as grades
\end{tabular} & $\begin{array}{l}\text { Most don't feel } \\
\text { successful as a reflection } \\
\text { of their academic } \\
\text { performance } \\
\text { - Success is defined as an } \\
\text { upward trajectory or } \\
\text { learning to be successful } \\
\text { in the sciences as well as } \\
\text { being retained in the } \\
\text { sciences } \\
\text { Success is also } \\
\text { contextualized to } \\
\text { recognize family } \\
\text { background and prior } \\
\text { academic preparation } \\
\text { Creating a contextual } \\
\text { definition of resilience is } \\
\text { important because many } \\
\text { students have not had } \\
\text { initial academic success }\end{array}$ & $\begin{array}{l}\text { Most don't feel } \\
\text { successful as a reflection } \\
\text { of their academic } \\
\text { performance. Success is } \\
\text { defined as an upward } \\
\text { trajectory or learning to } \\
\text { be successful in the } \\
\text { sciences. Some define } \\
\text { success as achievement } \\
\text { in a science related } \\
\text { profession. Success is } \\
\text { also contextualized to } \\
\text { recognize family } \\
\text { background and prior } \\
\text { academic preparation. } \\
\text { Creating a contextual } \\
\text { definition of resilience is } \\
\text { important because many } \\
\text { students have not had } \\
\text { initial academic success }\end{array}$ \\
\hline
\end{tabular}

\section{Discussion}

We studied how students in the Brandeis Science Posse perceived their success and how this related to the concept of resilience. All three groups of students experienced feelings of success in their study of science (Table 5). Within all three groups were definitions of success linked to research and/or a greater knowledge of science. However, most students described success based on their past or current academic progress. Well-resourced students equated success with academic achievement and high grades in their science classes. Their definition of academic success reflected the success that they had in high school, which continued into college, and which represented traditional definitions of what it meant to excel. In contrast, underrepresented students could not use the traditional measures of success, such as high grades, in order to define their experiences. If they had only judged success as grades, they would be left with feelings of failure. Instead, underrepresented students recognized that their backgrounds were very different from their wellresourced peers. As a result, they contextualized their idea of success to include their family and academic background and their upward trajectory in the sciences. Underrepresented students were also more likely to describe staying in the sciences as success. Science Posse Scholars, as with underrepresented 
students, described their success as how they had improved over time in their study of science. This was in juxtaposition to how they felt about their grades, which they almost uniformly described as "not successful". Like underrepresented students, Science Posse Scholars created a definition of success that recognized the journey that they undertook, not merely their grades. Science Posse Scholars were also more likely to equate future career outcomes with success in the sciences.

According to Stanton-Salazar and Sina's (2000) definition of resilience, underrepresented students and Science Posse Scholars were able to survive stressful events to positively shape future events. This understanding of success was present in the way that both groups described the study of science as a journey or an upward trajectory. This definition also reflected not only their current academic abilities, but their family background, academic background and the challenges they faced in the study of science, reflecting Cabrera and Padilla's (2004) definition of resilience. In addition, underrepresented students and Science Posse Scholars description of success reflected the ability to have a realistic self-assessment of their academic abilities, a trait that has been found to be linked to resilience and retention in the sciences (McGee, 2009). Wellresourced students demonstrated resilience in that they found the study of science challenging, but they succeeded through traditional measures such as grades. Underrepresented students and Science Posse Scholars demonstrated resilience in recognizing their current academic standing but also recognizing that their journey in the sciences was as important as more traditional outcomes such as grades.

We believe that resilience with respect to student self-perception of success in the sciences is playing a role in the retention of Science Posse Scholars in STEM. Science Posse Scholars reflect that success is the result of a journey through their undergraduate careers and do not equate success solely with grades or GPA. If a student understands where they start as a scientist at the beginning of their academic career in STEM and can identify multiple progress points such as increased scientific literacy, research progress, better preparation towards a career or graduate school, recognition of family background, etc., they are more likely to be retained.

\section{Acknowledgements}

We thank the Science Posse mentors, Susannah Gordon-Messer, Erin Jonasson, Kathryn Cousins, Marc Nahmani, Delora Gaskins and Cara Pina for their support and mentoring of the Scholars. We thank HHMI and the Carnegie Corporation of New York for financial support.

\section{References}

Alon, S., \& Tienda, M. (2005). Assessing the "Mismatch" Hypothesis: Differences in College Graduation Rates by Institutional Selectivity. Sociology of Education, 78 
(4), 294-315.

Bial, D. (2007). Identifying a Diverse Student Body: Selective College Admissions and Alternative Approaches. New Directions for Student Services, 118, 17-30.

Bowen, W., \& Bok, D. (1998). The Shape of the River. Princeton, NJ: Princeton University Press.

Cabera, N., \& Padilla, A.( 2004). Entering and succeeding in the "culture of college": The story of two Mexican heritage students. Hispanic Journal of Behavioral Sciences, 26(2), 152-170.

Huang, G., Taddese, B., \& Walter, E. (2000). Entry and Persistence of Women and Minorities in College Science and Engineering Education. Education Statistics Quarterly, 2(3), 59-60.

Lee, J., Nam S., Kim A., Kim B. Lee, M., \& Lee, S. (2013). Resilience: A metaanalytic approach. Journal of Counseling and Development, 91(3), 269-279.

Luthar, S., Cicchetti, D, \& Becker, B. (2000). The construct of resilience: A critical evaluation and guidelines for future work. Child Development, 71(3), 543-562.

Masten, A. (2001). Ordinary magic: Resilience processed in development. American Psychologists, 56(3), 227-238.

McGee, E. (2009). Race, identity, and resilience: Black college students negotiating success in mathematics and engineering. University of Illinois at Chicago, Pro Quest, UMI Dissertations Publishing. 3364621.

National Science Foundation, Division of Science Resources Statistics. (2004). Women, minorities, and persons with disabilities in science and engineering. NSF 04-317.

Stanton-Salazar, R. \& Spina, S. U. (2000). The network orientations of highly resilient urben minority yourth: a network-analytic account of minority socializaion and its edcuational implications. The Urban Review, 32(3), 227-261.

Strenta, A.C., Elliott, R., Adair, R., Matier, M., and Scott, J. (1994). Choosing and leaving science in highly selective institutions. Research in Higher Education, 35(5), 513-547. 
